\title{
Two-Step Sensing, Colorimetric and Ratiometric Fluorescent Probe for Rapid Detection of Bisulfite in Aqueous Solutions and in Living Cells
}

\author{
Xue-Lin Zheng, ${ }^{\dagger}$ Hao Li, ${ }^{\dagger}$ Wei Feng, Hong-Cheng Xia, and Qin-Hua Song*0 \\ Department of Chemistry, University of Science and Technology of China, Hefei 230026, China
}

Supporting Information

\begin{abstract}
Bisulfite and sulfite $\left(\mathrm{HSO}_{3}{ }^{-} / \mathrm{SO}_{3}{ }^{2-}\right.$ ) are not only widely used toxic chemicals but also active anions with important biological functions. Hence, the development of new detection methods for $\mathrm{HSO}_{3}{ }^{-} / \mathrm{SO}_{3}{ }^{2-}$ is important for environmental security and human health. In this paper, we report a symmetrical hemicyanine for the detection of $\mathrm{HSO}_{3}{ }^{-} / \mathrm{SO}_{3}{ }^{2-}$, SHC, which is constructed with $p$-diphthalaldehyde with trimethylbenzoindolium via condensation. The red fluorescent probe can fast respond to $\mathrm{HSO}_{3}{ }^{-} / \mathrm{SO}_{3}{ }^{2-}(<30$ s) to give cyan fluorescence, and its sensing process is twice nucleophilic additions, which were observed from fluores-
\end{abstract} cence response, initial ratiometric change, and subsequent

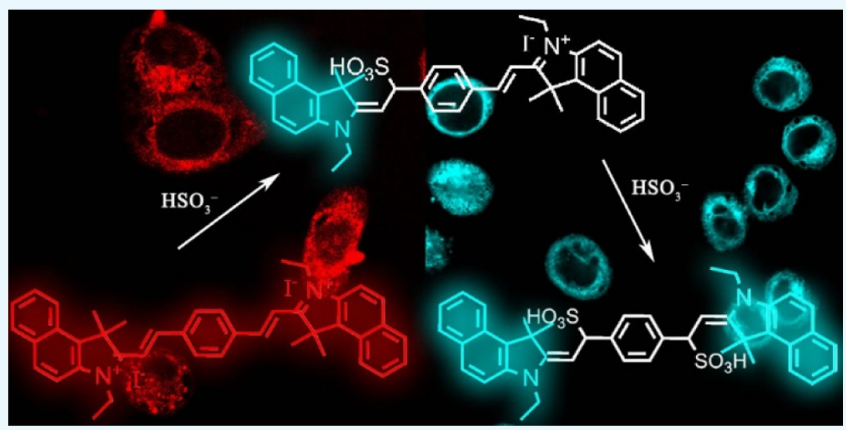
turn-on increment; especially in a low-concentration level, the ratiometric fluorescence measurement can eliminate environmental interference. This probe can achieve a quantitative detection of $\mathrm{HSO}_{3}^{-} / \mathrm{SO}_{3}{ }^{2-}$ in a wide concentration range. Furthermore, the probe SHC is a mitochondria-specific probe for ratiometric fluorescent detection of $\mathrm{HSO}_{3}{ }^{-} / \mathrm{SO}_{3}{ }^{2-}$ in living cells.

\section{INTRODUCTION}

Sulfur dioxide $\left(\mathrm{SO}_{2}\right)$ is both a main atmospheric pollutant and a valuable commercial reagent, and human exposure to $\mathrm{SO}_{2}$ has become increasingly widespread because of the combustion of fossil fuels and the industrial manufactures such as paper pulp manufacturing and metal processing. More and more medical studies have confirmed that expose to $\mathrm{SO}_{2}$ may cause not only respiratory responses ${ }^{1}$ but also lung cancer, cardiovascular diseases, and some neurological diseases, such as migraine headaches and brain cancer. ${ }^{2}$

$\mathrm{SO}_{2}$ dissolves in water to form a $\mathrm{pH}$-dependent equilibrium between bisulfite and sulfite $\left(\mathrm{HSO}_{3}{ }^{-} / \mathrm{SO}_{3}{ }^{2-}\right)$ with a molar ratio of about $3: 1$ in neutral aqueous solution. Bisulfite and sulfite are widely used as a preservative for beverages and food to prevent oxidation and bacterial growth. ${ }^{3}$ However, $\mathrm{HSO}_{3}{ }^{-} /$ $\mathrm{SO}_{3}{ }^{2-}$ is toxic in high doses, which is associated with allergic reactions and food intolerance symptoms. ${ }^{4}$ Hence, an acceptable daily intake (lower than $0.7 \mathrm{mg} \mathrm{kg}{ }^{-1}$ of body weight) has been issued by the Joint FAO/WHO Expert Committee on Food Additives. The labeling of products containing no more than $10 \mathrm{ppm}(125 \mu \mathrm{M})$ sulfite in foods or beverages has also been required by the U.S. Food and Drug Administration (FDA). ${ }^{5}$

Endogenous $\mathrm{HSO}_{3}{ }^{-} / \mathrm{SO}_{3}{ }^{2-}$ can be metabolically generated from thiol-containing amino acids, such as cysteine and glutathione. ${ }^{6}$ The studies have showed that $\mathrm{HSO}_{3}{ }^{-} / \mathrm{SO}_{3}{ }^{2-}$ has an endothelium-dependent vasorelaxing effect at low concentrations $(<450 \mu \mathrm{M})$ and also functions as messengers in cardiovascular systems. ${ }^{7}$ For this reason, the development of new detection methods for $\mathrm{HSO}_{3}{ }^{-} / \mathrm{SO}_{3}{ }^{2-}$ is important for environmental security and human health. Because of the advantages of simplicity, sensitivity, nontoxicity, and ease of operation, fluorescent probes have been recognized as efficient molecular tools for visualizing anions in living systems. ${ }^{8}$ In early years, some pioneer works about fluorescent probes for bisulfite/sulfite anion have been reviewed. ${ }^{9}$ In recent years, some excellent fluorescent probes have been designed by various effective reactions of $\mathrm{HSO}_{3}{ }^{-} / \mathrm{SO}_{3}{ }^{2-}$ including nucleophilic addition to an aldehyde, ${ }^{10}$ mediated levulinate cleavage, ${ }^{11}$ nucleophilic addition to an unsaturated bond, ${ }^{12}$ and others. ${ }^{13}$ However, there are still some limitations in the reported probes such as poor selectivity over biothiols or $\mathrm{H}_{2} \mathrm{~S}$ for most aldehyde- or levulinate-based fluorescent probes, long response time ( $>5 \mathrm{~min}$ for most probes), and high detection limits (>1 $\mu \mathrm{M}$ for half of probes). Hence, it is still a challenge to develop more reliable and quick response probes for $\mathrm{HSO}_{3}{ }^{-} / \mathrm{SO}_{3}{ }^{2-}$. In this work, we prepared a symmetrical dualhemicyanine ratiometric fluorescent probe SHC, which can detect $\mathrm{HSO}_{3}{ }^{-} / \mathrm{SO}_{3}{ }^{2-}$ in solutions fast and sensitively and achieve detection of $\mathrm{HSO}_{3}{ }^{-} / \mathrm{SO}_{3}{ }^{2-}$ in living cells (Scheme 1).

Received: August 6, 2018

Accepted: September 11, 2018

Published: September 25, 2018 
Scheme 1. Chemical Structures and the Sensing Reaction of SHC
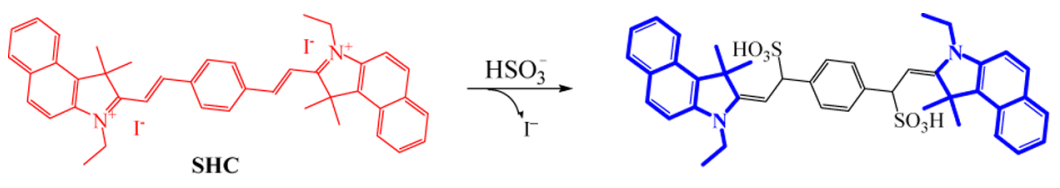

\section{RESULTS AND DISCUSSION}

2.1. Synthesis of Related Compounds. Synthesis of two compounds, 2 and the probe SHC, involves the same condensation reaction using the benzindole as a starting material (Scheme 2). The reaction of 2,3,3-trimethyl-1-

Scheme 2. Synthetic Procedure of the Probe $\mathrm{SHC}^{a}$

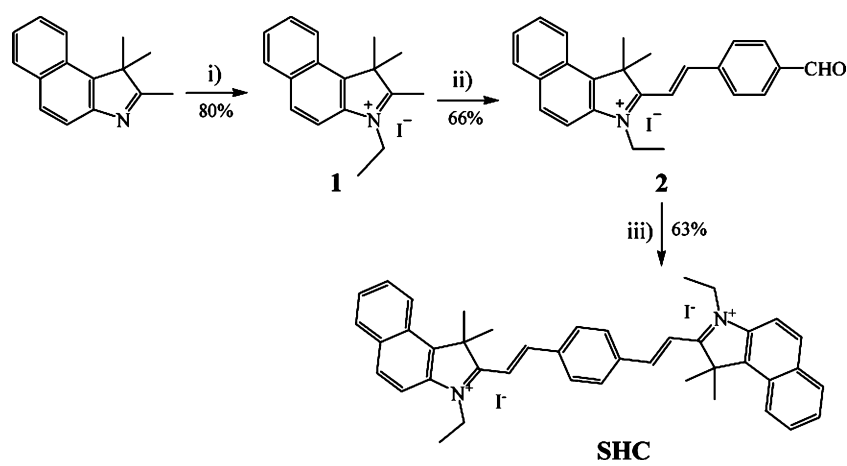

${ }^{a}$ (i) Ethyl iodide, toluene, $100{ }^{\circ} \mathrm{C}, 20 \mathrm{~h}$; (ii) $p$-diphthalalhyde, $\mathrm{NaOAc}$, acetic anhydride, under $\mathrm{N}_{2}, 60^{\circ} \mathrm{C}, 4 \mathrm{~h}$; (iii) $1, \mathrm{NaOAc}$, acetic anhydride, under $\mathrm{N}_{2}, 60{ }^{\circ} \mathrm{C}, 4 \mathrm{~h}$.

ethylbenz $[e]$ indolium iodide $(\mathbf{1})^{14}$ and excess diphthalaldehyde affords major product 2 (yield, 66\%). Under the same condition, the condensation of compound $\mathbf{2}$ with compound $\mathbf{1}$ forms the probe SHC in the yield of $63 \%$. Also, the reaction of compound 1 with diphthalaldehyde in the ratio of 2.5:1 gives directly the target product SHC. The structures of two compounds were fully characterized by ${ }^{1} \mathrm{H}$ NMR, ${ }^{13} \mathrm{C} \mathrm{NMR}$, and high-resolution mass spectroscopy (HRMS) analyses.

2.2. Spectral Response to Bisulfite. With the two compounds in hand, we first determined their photophysical properties. Figure 1 shows the $\mathrm{UV} /$ vis absorption and fluorescence spectra of $10 \mu \mathrm{M}$ SHC or compound 2 in a phosphate buffer solution [1\% dimethyl sulfoxide (DMSO), $\mathrm{pH} 7.4]$, a broad absorption band $(330-570 \mathrm{~nm}), \lambda_{\max } 470 \mathrm{~nm}$ for SHC and $367 \mathrm{~nm}$ (with a shoulder at $438 \mathrm{~nm}$ ) for 2 and fluorescence band (520-700 nm), $\lambda_{\max } 595 \mathrm{~nm}$ for SHC and
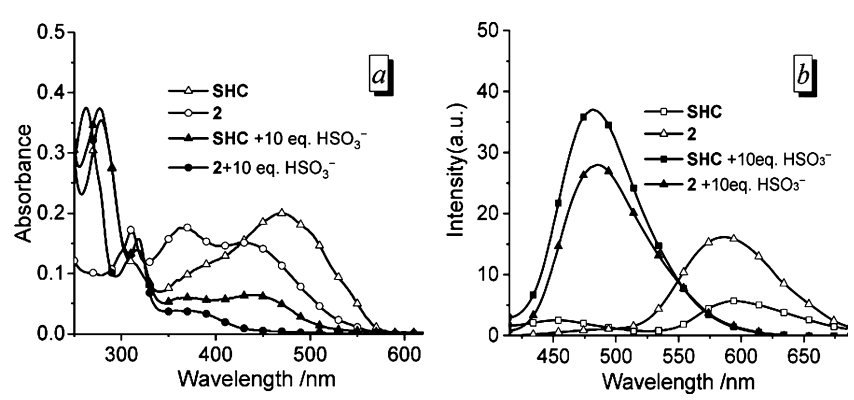

Figure 1. UV/vis absorption spectra (a) and fluorescence spectra [(b) $\left.\lambda_{\mathrm{ex}}=345 \mathrm{~nm}\right]$ of $10 \mu \mathrm{M}$ SHC (black) or 2 (blue) in the buffer solution (1\% DMSO, $\mathrm{pH} 7.4$ ) before and after the addition of 10 equiv $\mathrm{NaHSO}_{3}$.
$586 \mathrm{~nm}$ for 2. After the addition of 10 equiv of $\mathrm{NaHSO}_{3}$ for 30 min, the solutions of both SHC and 2 display almost disappearance of the long-wavelength band in both the absorption and fluorescence spectra and appearance of fluorescence at the short-wavelength band with a peak at 482 $\mathrm{nm}$. Obviously, fluorescence maxima of the probe SHC and the sensing product are about 595 and $482 \mathrm{~nm}$, respectively. Hence, the probe SHC would exhibit a colorimetric and ratiometric fluorescence response toward $\mathrm{HSO}_{3}{ }^{-}$.

To obtain more detailed information, we monitored the sensing process of $\mathrm{SHC}$ to $\mathrm{HSO}_{3}{ }^{-} / \mathrm{SO}_{3}{ }^{2-}$ with $\mathrm{UV} /$ vis absorption and fluorescence spectroscopies. After the addition of 10 equiv of $\mathrm{NaHSO}_{3}{ }^{-}$, the absorption spectra of $10 \mu \mathrm{M}$ SHC in the phosphate-buffered saline (PBS) solution (1\% DMSO, $\mathrm{pH}$ 7.4) decrease rapidly in the long-wavelength region $(330-570 \mathrm{~nm})$ and increase in the short-wavelength region (250-280 nm) (Figure 2a). The probe exhibits
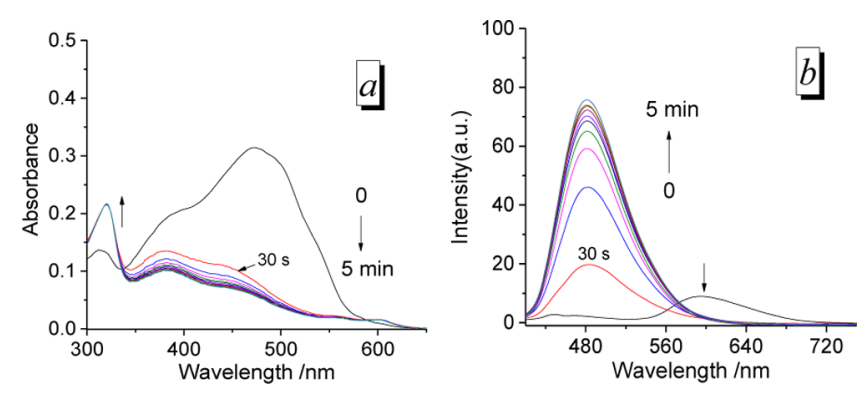

Figure 2. Time-dependent absorption (a) and fluorescence spectra [(b) $\left.\lambda_{\mathrm{ex}}=380 \mathrm{~nm}\right]$ of SHC $(10 \mu \mathrm{M}, \mathrm{pH} 7.4)$ upon addition of $\mathrm{NaHSO}_{3}$ (10 equiv) with $30 \mathrm{~s}$ intervals for $5 \mathrm{~min}$.

ratiometric fluorescent response to $\mathrm{HSO}_{3}{ }^{-}$, decreases and disappears in the long-wavelength region $(550-680 \mathrm{~nm})$, and increases in the short-wavelength region (450-550 nm) (Figure 2b). After the addition of $\mathrm{HSO}_{3}{ }^{-}$for $30 \mathrm{~s}, 90 \%$ absorption change and full disappearance of fluorescence in the long-wavelength region occur already. This implies that the probe can fast respond to $\mathrm{HSO}_{3}{ }^{-}$.

In addition, a long-time monitoring displays excellent photoand thermostability for both the probe and the sensing product shown in Figure S1 in the Supporting Information.

Furthermore, spectral response of SHC toward different equivalents of $\mathrm{HSO}_{3}^{-}(0-20$ equiv) was observed by $\mathrm{UV} /$ vis absorption and fluorescence spectroscopies (Figure 3), and more fluorescence titration data were provided in Figure S2a in the Supporting Information. As shown in Figure 3, the spectral changes show clearly two processes, fast decrease for the range of $\mathrm{NaHSO}_{3}$ (0-5 equiv) and slow decrease for 6-20 equiv of $\mathrm{NaHSO}_{3}$ in the long-wavelength-band absorbance (350-570 $\mathrm{nm}$ ) (Figure 3a), and gradual disappearance in the longwavelength-band fluorescence in less than 6 equiv of $\mathrm{HSO}_{3}{ }^{-}$ and increase in the short-wavelength-band emission centered at $480 \mathrm{~nm}$ for the range of 6-20 equiv of $\mathrm{NaHSO}_{3}$ (Figures $3 \mathrm{~b}$ and $\mathrm{S} 2 \mathrm{a}, \mathrm{b})$. The two processes could imply two-step sensing reactions of the dual-hemicyanine with $\mathrm{HSO}_{3}{ }^{-}$, the first 

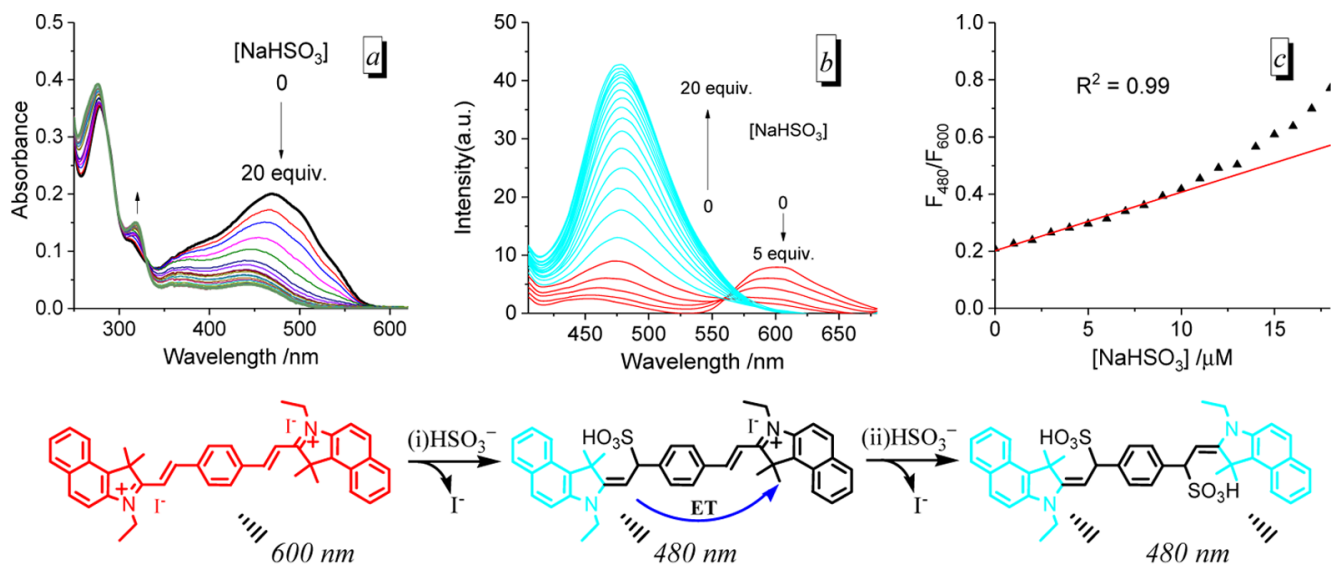

SHC

monoaddcut

diaddcut

Figure 3. Upper: UV/vis absorption (a) and fluorescence (b) spectra of $10 \mu \mathrm{M}$ SHC solution ( $\mathrm{pH}$ 7.4) upon additions of various amounts of $\mathrm{NaHSO}_{3}\left(0-20\right.$ equiv), incubation for $20 \mathrm{~min}$, under excitation at $380 \mathrm{~nm}$, and $(\mathrm{c})$ plot of the ratio of fluorescence intensities $\left(F_{480} / F_{600}\right)$ vs the concentration of $\mathrm{HSO}_{3}{ }^{-}(0-10 \mu \mathrm{M})$. Bottom: the sensing reactions of $\mathrm{SHC}$ with $\mathrm{HSO}_{3}{ }^{-}$.

addition in the range of $0-5$ equiv of $\mathrm{NaHSO}_{3}$ and the second addition for 6-20 equiv of $\mathrm{NaHSO}_{3}$. The fluorescence emission at 480 should be assigned to the benz $[e]$ indol moiety. The monoadduct could have a low fluorescence efficiency $(480 \mathrm{~nm})$ because of the intramolecular energy transfer (ET) from the benz $[e]$ indol moiety to the rest of the conjugation system, and the diadduct would emit more than twice as strong fluorescence as that of the monoadduct, shown in Figure 3 (bottom).

On the basis of the fluorescence titration, the fitting straight line was obtained from the plot of the ratio $\left(F_{480} / F_{600}\right)$ of fluorescence intensities versus the concentration of $\mathrm{NaHSO}_{3}$ $(0-10 \mu \mathrm{M})$ and the limit of detection (LOD) for SHC to $\mathrm{HSO}_{3}{ }^{-}$was obtained as $0.1 \mu \mathrm{M}$ from the calculation in terms of LOD $=3 \delta / k(n=11)$, where $k$ is the slope of the fitting straight line between the increment versus the concentration of $\mathrm{HSO}_{3}{ }^{-}$and $\delta$ is the standard deviation of a blank measurement (Figure 3c). The plot of $F_{480} / F_{600}$ versus $\left[\mathrm{NaHSO}_{3}\right]$ displays a good linear relationship because only monoaddition occurs in the concentration range of $\mathrm{NaHSO}_{3}(0-10 \mu \mathrm{M})$. Moreover, the disappearance of the fluorescence peak at $600 \mathrm{~nm}$ involves in the first addition (i); thus, the plot of fluorescence intensity at $600 \mathrm{~nm}$ versus the concentration of $\mathrm{NaHSO}_{3}$ should exhibit good linearity; besides, there will be a linear relation in the second addition (more than 5 equiv of $\mathrm{NaHSO}_{3}$ ). For this reason, from the plot of the fluorescence intensity at $600 \mathrm{~nm}$ $(0-50 \mu \mathrm{M})$ or $480 \mathrm{~nm}(50-110 \mu \mathrm{M})$ versus the concentration of $\mathrm{NaHSO}_{3}$, LODs of SHC were obtained as 85 and $91 \mathrm{nM}$, respectively, shown in Figure S2c,d. These values are much lower than the standard of $10 \mathrm{ppm}(125 \mu \mathrm{M})$ required by the U.S. Food and Drug Administration. ${ }^{5}$

At a low concentration level of $\mathrm{HSO}_{3}{ }^{-} / \mathrm{SO}_{3}{ }^{2-}$, the ratiometric fluorescent detection can eliminate environmental interference and the detection based on turn-on fluorescence increment at $600 \mathrm{~nm}$ for the high-concentration level. Hence, SHC can achieve detection of $\mathrm{HSO}_{3}{ }^{-} / \mathrm{SO}_{3}{ }^{2-}$ in a wide concentration.

2.3. Sensing Mechanism. To verify the sensing mechanism, ${ }^{1} \mathrm{H}$ NMR spectra of SHC before and after the addition of excess $\mathrm{NaHSO}_{3}$ were measured. As shown in Figure 4, the chemical shifts at 4.91, 2.08, and $1.59 \mathrm{ppm}$ are assigned to the proton $\mathrm{H}^{\mathrm{a}}, \mathrm{H}^{\mathrm{c}}$, and $\mathrm{H}^{\mathrm{b}}$ of the probe, respectively. After the addition of excess $\mathrm{NaHSO}_{3}$, these
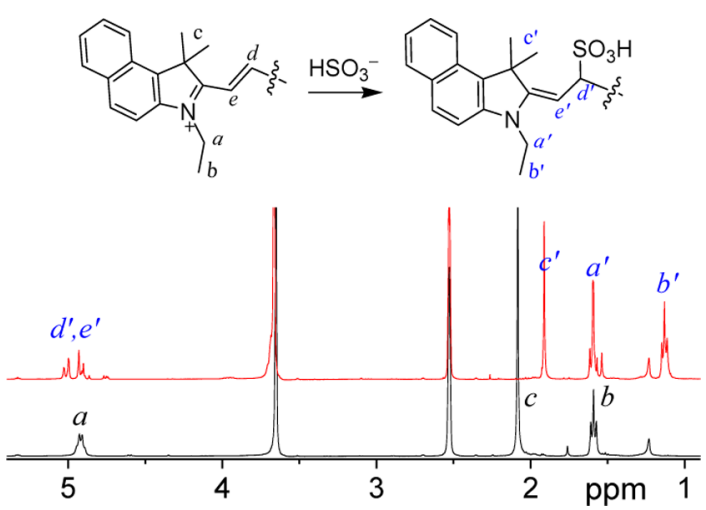

Figure 4. Partial ${ }^{1} \mathrm{H}$ NMR spectra of SHC in DMSO- $d_{6}-\mathrm{D}_{2} \mathrm{O}(\mathrm{v} / \mathrm{v}$ 9:1) before (black) and after (red) the addition of excess $\mathrm{NaHSO}_{3}$.

proton signals remove to high field, $1.91\left(c^{\prime}\right), 1.58\left(a^{\prime}\right)$, and $1.13\left(b^{\prime}\right) \mathrm{ppm}$, and the chemical shifts of the protons $(d, e)$ at carbon-carbon double bonds remove from the aromatic region to $4.96 \mathrm{ppm}\left(d^{\prime}, e^{\prime}\right)$. Moreover, the formation of the single adduct $\mathrm{SHC}-\mathrm{HSO}_{3}$ was confirmed by HRMS, where a dominant peak at a value of $\mathrm{m} / z 655.2992$ corresponding to $\left[\mathrm{SHC}-2 \mathrm{I}^{-}+\mathrm{HSO}_{3}\right]^{+}$(calcd 655.2989) shown in Figure S3. Therefore, the sensing reaction was confirmed to be the nucleophilic addition of the probe $\mathrm{SHC}$ with $\mathrm{HSO}_{3}{ }^{-}$.

2.4. Selectivity. To evaluate the selectivity of the probe for $\mathrm{HSO}_{3}{ }^{-} / \mathrm{SO}_{3}{ }^{2-}$, we measured the $\mathrm{UV} /$ vis absorption (Figure $5 \mathrm{a})$ and fluorescence spectra (Figure $5 \mathrm{~b}$ ) of SHC before and after the addition of various analytes, respectively. The absorption spectra of SHC displayed a large change only in the presence of $\mathrm{HSO}_{3}{ }^{-}$and little change for three biothiols, $\mathrm{Hcy}, \mathrm{GSH}$ and $\mathrm{Cys}$, and other analytes caused no significant change shown in Figure 5a. For fluorescence response, only $\mathrm{HSO}_{3}{ }^{-}$causes a large change in the fluorescence spectra of SHC (Figure $5 b$ ). The fluorescence profiles at $481 \mathrm{~nm}$ showed a remarkable selectivity for $\mathrm{HSO}_{3}{ }^{-}$over other analytes including $\mathrm{HS}^{-}$and biothiols. The increment of fluorescence ratio $\left(F_{481} / F_{595}\right)$ of SHC to $\mathrm{HSO}_{3}{ }^{-} / \mathrm{SO}_{3}{ }^{2-}$ is more than 200fold, shown in Figure $5 \mathrm{c}$.

The sensing behavior can be easily observed by the naked eyes from both the color change and fluorescence of solutions. As shown in Figure 5d,e, the SHC solution only to $\mathrm{HSO}_{3}{ }^{-}$ 

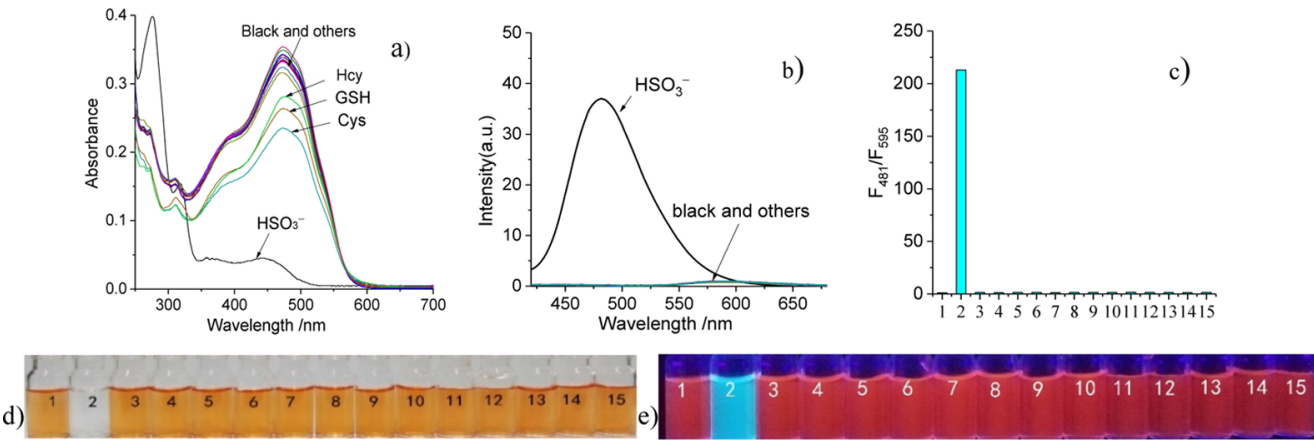

Figure 5. UV/vis absorption (a) and fluorescence spectra (b) of SHC $(10 \mu \mathrm{M})$ in the presence of 10 equiv of various analytes in the PBS solution $(1 \% \mathrm{DMSO}, \mathrm{pH} 7.4)$ recorded after $20 \mathrm{~min}$, and $(\mathrm{c})$ ratio $\left(F_{481} / F_{595}\right)$ of fluorescence intensities from $(\mathrm{b}), \lambda_{\mathrm{ex}}=345 \mathrm{~nm}$. (1): $\mathrm{Blank}^{2}(2): \mathrm{HSO}_{3}{ }^{-}$, (3): $\mathrm{CO}_{3}{ }^{2-},(4): \mathrm{F}^{-},(5): \mathrm{Br}^{-},(6): \mathrm{Cl}^{-},(7): \mathrm{I}^{-},(8): \mathrm{NO}_{2}{ }^{-},(9): \mathrm{NO}_{3}{ }^{-},(10): \mathrm{HPO}_{4}{ }^{2-},(11): \mathrm{HS}^{-},(12): \mathrm{SO}_{4}{ }^{2-},(13): \mathrm{Cys},(14): \mathrm{GSH}$, and $(15):$ Hcy. Photos for color change (d) and fluorescence (e) of corresponding solutions.

displays a color under room light and cyan fluorescence under a portable UV lamp (365 $\mathrm{nm})$. Hence, SHC reveals a high selectivity for $\mathrm{HSO}_{3}{ }^{-}$over other relevant analytes.

2.5. $\mathrm{pH}$ Effects and MTT Analysis. To assess the functions of SHC under physiological conditions, the absorption and fluorescence spectra of $5 \mu \mathrm{M}$ SHC with and without the addition of $\mathrm{HSO}_{3}^{-}$(5 equiv) solution were recorded at different $\mathrm{pH}$ values. The $\mathrm{pH}$-dependent absorption and fluorescence responses of $\mathrm{SHC}$ to $\mathrm{HSO}_{3}{ }^{-}$reveal a remarkable change of absorbance and significant fluorescence enhancements under physiological conditions ( $\mathrm{pH}$ 6-10) (Figure S4). This indicates that SHC could be used as a fluorescent probe in a biological system.

In order to detect $\mathrm{HSO}_{3}{ }^{-} / \mathrm{SO}_{3}{ }^{2-}$ in living cells, a MTT analysis was performed to assess the cytotoxicity of the probe. In the MTT assays, HepG2 cells were dealt with SHC at different concentrations from 10 to $30 \mu \mathrm{M}$ for $24 \mathrm{~h}$. The results show low toxicity to cultured cells under the experimental condition, and the cell viability is more than $90 \%$ for SHC at $10 \mu \mathrm{M}$ (Figure S5). These data show that the probe SHC has low cytotoxicity.

2.6. Cell Imaging. Finally, the probe $\mathbf{S H C}$ was utilized for imaging of HepG2 cells. HepG2 cells were seeded on a 24-well plate in a culture medium for $24 \mathrm{~h}$. No fluorescence was observed from nonstained HepG2 cells in both channels (Figure 6a-d). The HepG2 cells were incubated with SHC $(10 \mu \mathrm{M})$ for $30 \mathrm{~min}$, followed by PBS washing three times. Confocal fluorescence images exhibit no emission for the blue channel and red fluorescence for the red channel under excitation at $405 \mathrm{~nm}$ (Figure $6 \mathrm{e}-\mathrm{h}$ ). In contrast, after being further incubated with $0.1 \mathrm{mM} \mathrm{NaHSO}$ for $30 \mathrm{~min}$, the HepG2 cells emit bright blue fluorescence in the blue channel and no fluorescence for the red channel (Figure 6i-1). This shows that the probe SHC is a permeable cell membrane and potential fluorescent probe to detect $\mathrm{HSO}_{3}{ }^{-} / \mathrm{SO}_{3}{ }^{2-}$ in living cells.

Furthermore, cyanine derivatives could localize at mitochondria for their positive charge. To explore mitochondria localization, we performed costaining experiment with a commercial mitochondrial dye, MitoTracker Red FM. HepG2 cells were stained with SHC and the mitochondria dye in succession. As shown in Figure 7, the blue-channel image for SHC with $\mathrm{HSO}_{3}{ }^{-}$merged well with the red-channel image for the mitochondrial dye and good consistency for fluorescence intensity profiles across the line (Figure 7e,f). The colocalization coefficient (Pearson's coefficient) of SHC and

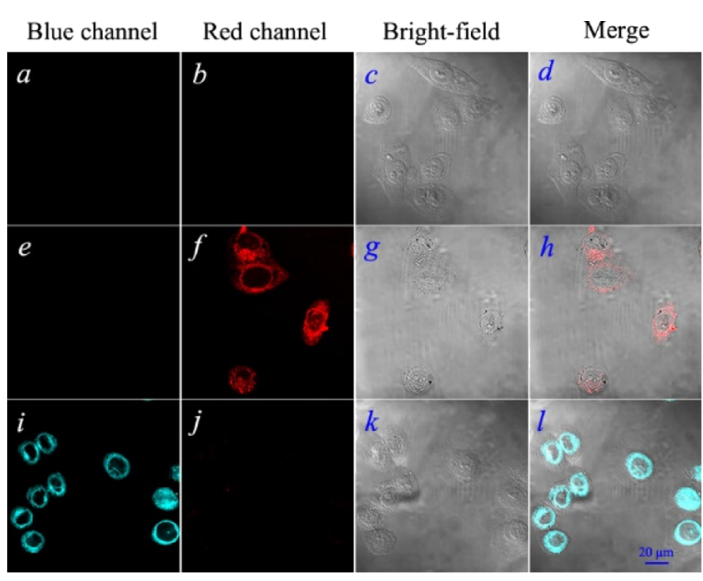

Figure 6. Confocal fluorescence images of HepG2 cells incubated without $(\mathrm{a}-\mathrm{d})$ and with $10 \mu \mathrm{M}$ SHC for $0.5 \mathrm{~h}(\mathrm{e}-\mathrm{h})$ and then 100 $\mu \mathrm{M} \mathrm{NaHSO}$ for $0.5 \mathrm{~h}(\mathrm{i}-1)$. Images were acquired using $405 \mathrm{~nm}$ excitation and signal collection from the blue channel $(420-550 \mathrm{~nm})$ and the red channel $(550-700 \mathrm{~nm})$.
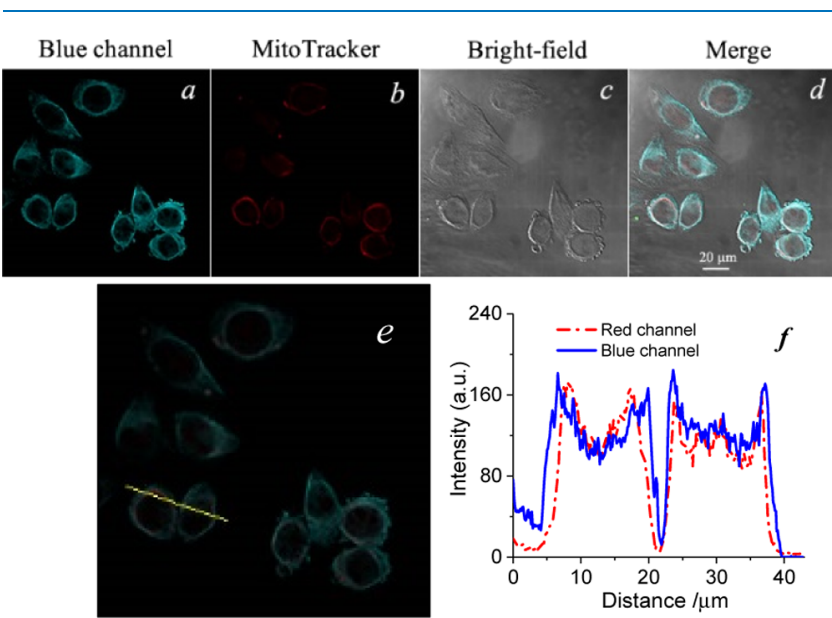

Figure 7. Confocal fluorescence images of HepG2 cells costained with SHC $(5 \mu \mathrm{M}, 0.5 \mathrm{~h})$, MitoTracker Red FM $(0.5 \mu \mathrm{M}, 0.5 \mathrm{~h})$, and 50 $\mu \mathrm{M} \mathrm{NaHSO}$ for $0.5 \mathrm{~h}$ successively. (a) Fluorescence image from the blue channel $(420-550 \mathrm{~nm}$ ), excitation at $405 \mathrm{~nm}$, (b) fluorescence image from the red channel $(665-750 \mathrm{~nm})$, excitation at $633 \mathrm{~nm},(\mathrm{c})$ bright-field images, (d) merge of $(a-c),(e)$ merge of $(a)$ and $(b, f)$ fluorescence profile of a given region [yellow line in (e)]. 
the mitochondria dye is 0.94 shown in Figure S6. The high overlap coefficient indicates that SHC can cumulate to detect $\mathrm{HSO}_{3}{ }^{-}$in the mitochondria.

\section{CONCLUSIONS}

In summary, we prepared a symmetrical dual-hemicyanine dye SHC for the detection of $\mathrm{HSO}_{3}{ }^{-} / \mathrm{SO}_{3}{ }^{2-}$ from the condensation of $p$-diphthalaldehyde with triethylindolium. The probe SHC can fast respond $\mathrm{HSO}_{3}{ }^{-} / \mathrm{SO}_{3}{ }^{2-}$ within $30 \mathrm{~s}$ as colorimetric and ratiometric fluorescence changes and observed conveniently by naked eyes, and LOD is as low as $85 \mathrm{nM}$. The sensing process is twice nucleophilic additions which can be observed with absorption and fluorescence spectroscopies, intimal ratiometric fluorescence, and subsequent fluorescent increment, and this can achieve detection of $\mathrm{HSO}_{3}{ }^{-} / \mathrm{SO}_{3}{ }^{2-}$ in a wide concentration range. Furthermore, cell imaging experiments reveal that $\mathrm{SHC}$ can detect $\mathrm{HSO}_{3}{ }^{-} /$ $\mathrm{SO}_{3}{ }^{2-}$ mitochondria specifically in living cells. The new probe is promising to be utilized in a variety of chemical and biological applications.

\section{EXPERIMENTAL SECTION}

4.1. Materials and Instrumentation. All of the chemicals except synthesized compounds were obtained from commercial channels and were used as received without further purification. ${ }^{1} \mathrm{H}$ and ${ }^{13} \mathrm{C}$ NMR spectra were recorded in DMSO- $d_{6}$ or $\mathrm{CDCl}_{3}$ with a Bruker AV spectrometer operating at 400 and $100 \mathrm{MHz}$, respectively, and chemical shifts were shown in parts per million using tetramethylsilane (TMS) as the internal standard. High-resolution mass spectra were obtained from a Thermo LTQ Orbitrap mass spectrometer. $\mathrm{UV} /$ vis absorption and fluorescence emission spectra were recorded with a UV/vis spectrometer (Shimadzu UV-2450) and a spectrofluorophotometer (Shimadzu RF-5301PC), respectively. Sample solutions for all measurements are phosphate buffer solutions (1\% DMSO, $\mathrm{pH} 7.4$ ). Water for preparing samples was purified with a Millipore system.

4.2. Synthesis of 3-Ethyl-1,1,2-trimethyl-1H-benzo[e]indol-3-ium iodide $^{14}$ (1). 1,1,2-trimethyl-1H-benzo[e] indole $(400 \mathrm{mg}, 1.9 \mathrm{mmol})$ and ethyl iodide $(0.66 \mathrm{~mL}, 8.3$ $\mathrm{mmol}$ ) placed in a round-bottom flask were dissolved in $15 \mathrm{~mL}$ of toluene and stirred at $100{ }^{\circ} \mathrm{C}$ for $20 \mathrm{~h}$. Cooling to room temperature, the solvent toluene was removed using a rotary evaporator. The obtained crude product was purified by column chromatography on silica (DCM/MeOH, v/v 20:1) to afford compound $\mathbf{1}(600 \mathrm{mg}, 80 \%)$ as a black solid.

4.3. Synthesis of (E)-2-(4-Acetylstyryl)-3-ethyl-1,1dimethyl-1H-benzo[e]indol-3-ium (2). Compound 1 (150 $\mathrm{mg}, 0.41 \mathrm{mmol})$ and $p$-diphthalaldehyde $(100 \mathrm{mg}, 0.75 \mathrm{mmol})$ and sodium acetate $(23 \mathrm{mg}, 0.28 \mathrm{mmol})$ were dissolved in acetic anhydride and stirred under nitrogen atmosphere at 60 ${ }^{\circ} \mathrm{C}$ for $6 \mathrm{~h}$. After cooling to room temperature, the rude product was collected by filtration. The rude product was washed with ethyl ether $(20 \mathrm{~mL})$ and purified using column chromatography (DCM/MeOH, v/v 40:1) to give compound 2 (130 mg, 66\%). ${ }^{1} \mathrm{H}$ NMR (400 MHz, DMSO- $d_{6}, 25{ }^{\circ} \mathrm{C}$, TMS ): $\delta 10.14(\mathrm{~s}, 1 \mathrm{H}, \mathrm{CHO}), 8.60(\mathrm{~d}, J=16.8 \mathrm{~Hz}, 1 \mathrm{H}, \mathrm{HC}=$ $\mathrm{CH}), 8.48$ (d, $J=8.0 \mathrm{~Hz}, 3 \mathrm{H}, \mathrm{Ar}-\mathrm{H}), 8.33(\mathrm{~d}, J=3.2 \mathrm{~Hz}, 1 \mathrm{H}$, Ar-H), 8.25 (d, $J=8.0 \mathrm{~Hz}, 1 \mathrm{H}, \mathrm{Ar}-\mathrm{H}), 8.19$ (d, $J=8.8 \mathrm{~Hz}, 1 \mathrm{H}$, Ar-H), 8.12 (d, J = 8.4 Hz, 2H, Ar-H), 7.92-7.75 (m, 3H, $\mathrm{HC}=\mathrm{CH}, \operatorname{Ar}-\mathrm{H}), 4.93\left(\mathrm{q}, J=7.2 \mathrm{~Hz}, 2 \mathrm{H}, \mathrm{CH}_{2}\right), 2.06(\mathrm{~s}, 6 \mathrm{H}$, $\left.\mathrm{CH}_{3}\right), 1.56\left(\mathrm{t}, \mathrm{J}=7.2 \mathrm{~Hz}, 3 \mathrm{H}, \mathrm{CH}_{3}\right) \mathrm{ppm} .{ }^{13} \mathrm{C} \mathrm{NMR}(100$
$\mathrm{MHz}, \mathrm{CDCl}_{3}, 25{ }^{\circ} \mathrm{C}$, TMS): $\delta 193.3,182.4,150.9,140.1$, $139.9,138.7,138.6,133.9,131.7,131.3,130.3,129.1,128.1$, 127.2, 123.8, 115.3, 113.9, 79.7, 54.7, 43.5, 25.6, 14.7 ppm. FTMS + cESI: $m / z$ calcd for $\mathrm{C}_{26} \mathrm{H}_{26} \mathrm{NO}, 354.1852([\mathrm{M}-$ $\left.\left.\mathrm{I}^{-}\right]^{+}\right)$; found, 354.1843.

4.4. Synthesis of $2,2^{\prime}-\left(\left(1 E, 1^{\prime} E\right)-1,4-P h e n y l e n e b i s-\right.$ (ethene-2,1-diyl))bis(3-ethyl-1,1-dimethyl-1H-benzo[e] indol-3-ium)iodide (SHC). Compound 1 (100 mg, 0.27 $\mathrm{mmol})$ and compound $2(100 \mathrm{mg}, 0.21 \mathrm{mmol})$ were placed in a round-bottomed flask with $10 \mathrm{~mL}$ of acetic anhydride, and sodium acetate $(47 \mathrm{mg}, 0.57 \mathrm{mmol})$ was further added. The mixture reacts at $60{ }^{\circ} \mathrm{C}$ for $6 \mathrm{~h}$ under nitrogen protection. Cooling to room temperature, ethyl ether $(20 \mathrm{~mL})$ was added, washed, and filtrated to give a rude product. The rude product was purified using column chromatography (DCM/MeOH, v/ $\mathrm{v} 40: 1)$ to give the target compound, SHC $(110 \mathrm{mg}, 63 \%) .{ }^{1} \mathrm{H}$ NMR (400 MHz, DMSO- $d_{6}, 25{ }^{\circ} \mathrm{C}$, TMS $): \delta 8.61(d, J=16.4$ $\mathrm{Hz}, 2 \mathrm{H}, \mathrm{HC}=\mathrm{CH}), 8.47(d, J=8.8 \mathrm{~Hz}, 6 \mathrm{H}, \operatorname{Ar}-\mathrm{H}), 8.34(d, J$ $=12.8 \mathrm{~Hz}, 2 \mathrm{H}, \mathrm{Ar}-\mathrm{H}), 8.27$ (d, $J=8.0 \mathrm{~Hz}, 2 \mathrm{H}, \mathrm{Ar}-\mathrm{H}), 8.19$ (d, $J=8.8 \mathrm{~Hz}, 2 \mathrm{H}, \mathrm{Ar}-\mathrm{H}), 7.92-7.77(m, 6 \mathrm{H}, \mathrm{HC}=\mathrm{CH}, \mathrm{Ar}-\mathrm{H})$, $4.93\left(d, J=6.0 \mathrm{~Hz}, 4 \mathrm{H}, \mathrm{CH}_{2}\right), 2.09\left(\mathrm{~s}, 12 \mathrm{H}, \mathrm{CH}_{3}\right), 1.59(\mathrm{t}, J=$ $\left.7.2 \mathrm{~Hz}, 6 \mathrm{H}, \mathrm{CH}_{3}\right) \mathrm{ppm} .{ }^{13} \mathrm{C} \mathrm{NMR}\left(100 \mathrm{MHz}, \mathrm{CDCl}_{3}, 25{ }^{\circ} \mathrm{C}\right.$, TMS): $\delta 182.2,151.1,139.8,138.7,138.6,133.9,131.8,131.4$, 130.6, 129.1, 128.1, 127.2, 123.8, 114.6, 113.9, 55.4, 54.6, 25.8, 14.7 ppm. FTMS + cESI: $m / z$ calcd for $\mathrm{C}_{42} \mathrm{H}_{42} \mathrm{~N}_{2}, 574.3337$ $\left(\left[\mathrm{M}-2 \mathrm{I}^{-}\right]^{2+}\right)$; found, $287.1663(z=2)$.

4.5. Cell Cultures and MTT Assays. HepG2 cells were seeded in Dulbecco's modified Eagle's medium (DMEM) supplemented with $10 \%$ fetal bovine serum in an atmosphere of $95 \%$ air and $5 \% \mathrm{CO}_{2}$ at $37{ }^{\circ} \mathrm{C}$ for MTT analysis. The cells were placed in a 96-well plate, and added the probe SHC in different concentrations $(0-30 \mu \mathrm{M})$, and incubated at $37{ }^{\circ} \mathrm{C}$ in an atmosphere of $95 \%$ air and $5 \% \mathrm{CO}_{2}$ for $24 \mathrm{~h}$. After removing the culture medium, $5 \mathrm{mg} \mathrm{mL}^{-1}(10 \mu \mathrm{L})$ MTT reagent in PBS was added into each well and incubated for $4 \mathrm{~h}$. During this period, active mitochondria of viable cells reduce MTT to purple formazan, and unreduced MTT was discarded. The formazan precipitate in each well was dissolved by adding DMSO $(150 \mu \mathrm{L})$ and then measured spectrophotometrically with a microplate reader at $570 \mathrm{~nm}$. Finally, the cytotoxicity of each sample was expressed as the percentage of cell viability relative to the untreated cells.

4.6. Cell Fluorescence Images. HepG2 cells were seeded on the coverslips in 24-well plates and incubated in a humidified $5 \% \mathrm{CO}_{2}$ atmosphere for $24 \mathrm{~h}$ with the complete DMEM containing $10 \%$ fetal calf serum at $37{ }^{\circ} \mathrm{C}$ DMSO solution of SHC was added to a well to give a concentration of $10 \mu \mathrm{M}$, and the volume ratio of the DMSO/culture medium is 1:100. After being incubated for $30 \mathrm{~min}$, and then the cells were washed three times with PBS buffer. The cells were further treated with $0.1 \mathrm{mM} \mathrm{NaHSO}$ for $30 \mathrm{~min}$, then removed the culture medium, and washed three times with PBS buffer. The cellular localization was visualized under a laser scanning confocal microscope (LSM 710 Meta, Carl Zeiss Inc., Thornwood, NY). The green fluorescence of cells was collected with $420-550 \mathrm{~nm}$ channel under excitation at 405, $665-750 \mathrm{~nm}$ channel at excitation at $633 \mathrm{~nm}$.

\section{ASSOCIATED CONTENT}

\section{Supporting Information}

The Supporting Information is available free of charge on the ACS Publications website at DOI: 10.1021/acsomega.8b01917. 
Stability of SHC and the sensing product, spectral response of $\mathrm{SHC}$ to $\mathrm{HSO}_{3}{ }^{-}, \mathrm{MS}$ evidence for the sensing mechanism, $\mathrm{pH}$ effects on the sensing reaction, MTT assays, and NMR spectra of new compounds (PDF)

\section{AUTHOR INFORMATION}

\section{Corresponding Author}

*E-mail: qhsong@ustc.edu.cn (Q.-H.S.).

ORCID

Qin-Hua Song: 0000-0001-6501-1382

\section{Author Contributions}

${ }^{\dagger}$ X.-L.Z. and H.L. contributed equally.

\section{Notes}

The authors declare no competing financial interest.

\section{ACKNOWLEDGMENTS}

We are grateful for financial support from the National Natural Science Foundation of China (grant nos. 21272224, 21772188) and Anhui Provincial Natural Science Foundation (grant no. 1708085MB33).

\section{REFERENCES}

(1) Iwasawa, S.; Kikuchi, Y.; Nishiwaki, Y.; Nakano, M.; Michikawa, T.; Tsuboi, T.; et al. Effects of $\mathrm{SO}_{2}$ on Respiratory System of Adult Miyakejima Resident 2 Years after Returning to the Island. J. Occup. Health 2009, 51, 38-47.

(2) Sang, N.; Yun, Y.; Li, H.; Hou, L.; Han, M.; Li, G. SO Inhalation Contributes to the Development and Progression of Ischemic Stroke in the Brain. Toxicol. Sci. 2010, 114, 226-236.

(3) Wedzicha, B. L. Chemistry of Sulphur Dioxide in Foods; Elsevier Applied Science Publishers: London and New York, 1984; pp 275311.

(4) Taylor, S. L.; Higley, N. A.; Bush, R. K. Sulfites in Foods: Uses, Analytical Methods, Residues, Fate, Exposure Assessment, Metabolism, Toxicity, and Hypersensitivity. Adv. Food Res. 1986, 30, 1-76.

(5) (a) Yu, C.; Luo, M.; Zeng, F.; Wu, S. A fast-responding fluorescent turn-on sensor for sensitive and selective detection of sulfite anions. Anal. Methods 2012, 4, 2638-2640. (b) Koch, M.; Köppen, R.; Siegel, D.; Witt, A.; Nehls, I. Determination of total sulfite in wine by ion chromatography after in-sample oxidation. $J$. Agric. Food Chem. 2010, 58, 9463-9467. (c) Sulfites in Standardized Food. Code of Federal Regulations, Part 130, Title 21, 2018. (d) WHO Food Additives Series NO. 5; World Health Organization: Geneva, 1974.

(6) (a) Stipanuk, M. Metabolism of sulfur-containing amino acids. Annu. Rev. Nutr. 1986, 6, 179-209. (b) Stipanuk, M. H.; Ueki, I. Dealing with methionine/homocysteine sulfur: cysteine metabolism to taurine and inorganic sulfur. J. Inherited Metab. Dis. 2011, 34, 1732.

(7) (a) Li, J.; Li, R.; Meng, Z. Sulfur dioxide upregulates the aortic nitric oxide pathway in rats. Eur. J. Pharmacol. 2010, 645, 143-150. (b) Wang, X.-B.; Jin, H.-F.; Tang, C.-S.; Du, J.-B. The biological effect of endogenous sulfur dioxide in the cardiovascular system. Eur. J. Pharmacol. 2011, 670, 1-6.

(8) (a) Chan, J.; Dodani, S. C.; Chang, C. J. Reaction-based smallmolecule fluorescent probes for chemoselective bioimaging. Nat. Chem. 2012, 4, 973-984. (b) Schäferling, M. The art of fluorescence imaging with chemical sensors. Angew. Chem., Int. Ed. 2012, 51, 3532-3554.

(9) Lin, V. S.; Chen, W.; Xian, M.; Chang, C. J. Chemical probes for molecular imaging and detection of hydrogen sulfide and reactive sulfur species in biological systems. Chem. Soc. Rev. 2015, 44, 45964618 , and references therein .

(10) (a) Liu, X.; Yang, Q.; Chen, W.; Mo, L.; Chen, S.; Kang, J.; Song, X. A ratiometric fluorescent probe for rapid, sensitive and selective detection of sulfur dioxide with large Stokes shifts by single wavelength excitation. Org. Biomol. Chem. 2015, 13, 8663-8668. (b) Yu, S.; Yang, X.; Shao, Z.; Feng, Y.; Xi, X.; Shao, R.; Guo, Q.; Meng, X. A TICT based two-photon fluorescent probe for bisulfite anion and its application in living cells. Sens. Actuators, B 2016, 235, 362-369. (c) Yin, C.; Li, X.; Yue, Y.; Chao, J.; Zhang, Y.; Huo, F. A new fluorescent material and its application in sulfite and bisulfite bioimaging. Sens. Actuators, B 2017, 246, 615-622.

(11) Zhang, H.; Xue, S.; Feng, G. A colorimetric and near-infrared fluorescent turn-on probe for rapid detection of sulfite. Sens. Actuators, B 2016, 231, 752-758.

(12) (a) Zhang, Q.; Zhang, Y.; Ding, S.; Zhang, H.; Feng, G. A nearinfrared fluorescent probe for rapid, colorimetric and ratiometric detection of bisulfite in food, serum, and living cells. Sens. Actuators, $B$ 2015, 211, 377-384. (b) Li, D.; Shi, Y.; Tian, X.; Wang, M.; Huang, B.; Li, F.; Li, S.; Zhou, H.; Wu, J.; Tian, Y. Fluorescent probes with dual-mode for rapid detection of $\mathrm{SO}_{2}$ derivatives in living cells: Ratiometric and two-photon fluorescent sensors. Sens. Actuators, $B$ 2016, 233, 1-6. (c) Zhang, H.; Huang, Z.; Feng, G. Colorimetric and ratiometric fluorescent detection of bisulfite by a new HBThemicyanine hybrid. Anal. Chim. Acta 2016, 920, 72-79. (d) Xu, J.; Pan, J.; Jiang, X.; Qin, C.; Zeng, L.; Zhang, H.; Zhang, J. F. A mitochondria-targeted ratiometric fluorescent probe for rapid, sensitive and specific detection of biological $\mathrm{SO}_{2}$ derivatives in living cells. Biosens. Bioelectron. 2016, 77, 725-732. (e) Li, H.; Yao, Q.; Fan, J.; Hu, C.; Xu, F.; Du, J.; Wang, J.; Peng, X. A Fluorescent Probe for Ratiometric Imaging of $\mathrm{SO}_{2}$ Derivatives in Mitochondria of Living Cells. Ind. Eng. Chem. Res. 2016, 55, 1477-1483. (f) Yang, J.; Li, K.; Hou, J.-T.; Li, L.-L.; Lu, C.-Y.; Xie, Y.-M.; Wang, X.; Yu, X.-Q. Novel Tumor-Specific and Mitochondria-Targeted near-Infrared-Emission Fluorescent Probe for $\mathrm{SO}_{2}$ Derivatives in Living Cells. ACS Sens. 2016, 1, 166-172. (g) Su, X.; Hu, R.; Li, X.; Zhu, J.; Luo, F.; Niu, X.; Li, M.; Zhao, Q. Hydrophilic indolium cycloruthenated complex system for visual detection of bisulfite with a large red shift in absorption. Inorg. Chem. 2016, 55, 745-754. (h) Samanta, S.; Dey, P.; Ramesh, A.; Das, G. A solo fluorogenic probe for the real-time sensing of $\mathrm{SO}_{3}{ }^{2-}$ and $\mathrm{SO}_{4}{ }^{2-} / \mathrm{HSO}_{4}{ }^{-}$in aqueous medium and live cells by distinct turn-on emission signals. Chem. Commun. 2016, 52, 1038110384. (i) Yang, X.; Zhou, Y.; Zhang, X.; Yang, S.; Chen, Y.; Guo, J.; Li, X.; Qing, Z.; Yang, R. A TP-FRET-based two-photon fluorescent probe for ratiometric visualization of endogenous sulfur dioxide derivatives in mitochondria of living cells and tissues. Chem. Commun. 2016, 52, 10289-10292. (j) Liu, Y.; Li, K.; Xie, K.-X.; Li, L.-L.; Yu, K.-K.; Wang, X.; Yu, X.-Q. A water-soluble and fast-response mitochondria-targeted fluorescent probe for colorimetric and ratiometric sensing of endogenously generated $\mathrm{SO}_{2}$ derivatives in living cells. Chem. Commun. 2016, 52, 3430-3433. (k) Wang, G.; Chen, H.; Chen, X.; Xie, Y. A novel carbazole-based mitochondriatargeted ratiometric fluorescent probe for bisulfite in living cells. RSC Adv. 2016, 6, 18662-18666. (1) Li, D.-P.; Wang, Z.-Y.; Cao, X.-J.; Cui, J.; Wang, X.; Cui, H.-Z.; Miao, J.-Y.; Zhao, B.-X. A mitochondriatargeted fluorescent probe for ratiometric detection of endogenous sulfur dioxide derivatives in cancer cells. Chem. Commun. 2016, 52, 2760-2763. (m) Zhang, L.-J.; Wang, Z.-Y.; Liu, J.-T.; Miao, J.-Y.; Zhao, B.-X. A rational design of ratiometric fluorescent probes based on new ICT/FRET platform and imaging of endogenous sulfite in living cells. Sens. Actuators, B 2017, 253, 19-26. (n) Li, M.; Feng, W.; Zhang, H.; Feng, G. An aza-coumarin-hemicyanine based nearinfrared fluorescent probe for rapid, colorimetric and ratiometric detection of bisulfite in food and living cells. Sens. Actuators, B 2017 243, 51-58. (o) Xu, W.; Ma, P.; Diao, Q.; Xu, L.; Liu, X.; Sun, Y.; Wang, X.; Song, D. A highly selective ratiometric fluorescent and chromogenic probe for sulfite and its applications in imaging of living cells and zebrafish in vivo. Sens. Actuators, B 2017, 252, 86-94. (p) Ma, Y.; Tang, Y.; Zhao, Y.; Gao, S.; Lin, W. Two-Photon and Deep-Red Emission Ratiometric Fluorescent Probe with a Large Emission Shift and Signal Ratios for Sulfur Dioxide: Ultrafast Response and Applications in Living Cells, Brain Tissues, and Zebrafishes. Anal. Chem. 2017, 89, 9388-9393. (q) Zhang, W.; Liu, 
T.; Huo, F.; Ning, P.; Meng, X.; Yin, C. Reversible Ratiometric Fluorescent Probe for Sensing Bisulfate $/ \mathrm{H}_{2} \mathrm{O}_{2}$ and Its Application in Zebrafish. Anal. Chem. 2017, 89, 8079-8083. (r) Yu, H.; Du, L.; Guan, L.; Zhang, K.; Li, Y.; Zhu, H.; Sun, M.; Wang, S. A ratiometric fluorescent probe based on the pi-stacked graphene oxide and cyanine dye for sensitive detection of bisulfite. Sens. Actuators, B 2017, 247, 823-829. (s) Ma, W.; Du, J.; Yin, J.; Fan, J.; Long, S.; Peng, X. Quantitative recognition and ratiometric cell imaging of $\mathrm{HSO}^{3-}$ inspired of confined-space based FRET system within human serum albumin. Sens. Actuators, B 2018, 267, 104-110. (t) Samanta, S.; Halder, S.; Dey, P.; Manna, U.; Ramesh, A.; Das, G. A ratiometric fluorogenic probe for the real-time detection of $\mathrm{SO}_{3}{ }^{2-}$ in aqueous medium: application in a cellulose paper based device and potential to sense $\mathrm{SO}_{3}{ }^{2-}$ in mitochondria. Analyst 2018, 143, 250-257. (u) Lan, J.-S.; Zeng, R.-F.; Ding, Y.; Zhang, Y.; Zhang, T.; Wu, T. A simple pyrene-hemicyanine fluorescent probe for colorimetric and ratiometric detection of $\mathrm{SO}_{2}$ derivatives in the mitochondria of living cells and zebrafish in vivo. Sens. Actuators, B 2018, 268, 328-337.

(13) Li, G.; Chen, Y.; Wang, J.; Wu, J.; Gasser, G.; Ji, L.; Chao, H. Direct imaging of biological sulfur dioxide derivatives in vivo using a two-photon phosphorescent probe. Biomaterials 2015, 63, 128-136.

(14) Ito, S.; Muguruma, N.; Kakehashi, Y.; Hayashi, S.; Okamura, S.; Shibata, H.; Okahisa, T.; Kanamori, M.; Shibamura, S.; Takesako, K.; Nozawa, M.; Ishida, K.; Shiga, M. Development of fluorescenceemitting antibody labeling substance by near-infrared ray excitation. Bioorg. Med. Chem. Lett. 1995, 5, 2689-2694. 